\title{
THE OCTAGON OF THE NIDAROS CATHEDRAL IN TRONDHEIM: CONSTRUCTIVE, HISTORICAL AND TECHNICAL STUDIES ABOUT ITS RESTORATION PROCEDURES UNTIL THE 19TH CENTURY
}

\author{
A. Menargues Rajadell ${ }^{1,2}$ \\ ${ }^{1}$ Department of Building History and Building Archaeology, Otto-Friedrich-University of Bamberg, KDWT, Am Zwinger 4-6, \\ 96047 Bamberg, Germany - angel.menargues@uni-bamberg.de \\ ${ }^{2}$ Construction Engineering - Doctoral School - Department of Civil and Environmental Engineering (ECA); \\ Universitat Politècnica de Catalunya; Campus Nord UPC, 08034 Barcelona, Spain - angelmenargues@ gmail.com
}

Commission II, WG II/8

KEY WORDS: Nidaros Cathedral, Restoration, $19^{\text {th }}$ Century, 3D-Scan, Mapping, Building Archaeology

\begin{abstract}
:
The history of restorations and renovations on the octagonal apse or Shrine Chapel of the Nidaros Cathedral in Trondheim began already soon after the construction of its lower inner wall and main arches, directly after a first major fire in 1328, and it has continued even if irregularly in all its areas, especially in two major constructive phases during the early $16^{\text {th }}$, with the archbishop Valkendorff, and the late $19^{\text {th }}$ centuries, with the origin of the Restoration Office and Workshops Nidarosdomens Restaureringsarbeider on 1869. A multidisciplinar and heterogeneous approach of the research of archival documentation, historical photographs and notes on the architect journals has been graphically located through photogrammetry and 3D-Scanning elevations, confirmed by mortar sample analysis and an exhaustive mapping on site of all the surfaces of the octagon, in a Building Archaeological analysis. The example of this methodological procedure is to be shown in general terms for the whole building, whilst concretizing with a deeper level of details in the case of the north-western bay of this apse, an area which contain and can illustrate all these diverse restoration and renovation phases and its characteristics. Further analysis in other areas and the combination and merging feasibility among historical-artistic, archaeological-architectonic and geometrical-modelling data are also included in this article, yet in a second term.
\end{abstract}

\section{INTRODUCTION}

\subsection{The history of the Octagon of the Nidaros Cathedral}

The construction of the octagonal apse of the Nidaros Cathedral in Trondheim, Norway, dedicated to the figure of Saint Olav and unique in its form and significance in the history of medieval European architecture (Fischer, 1965; Ekroll, 2000, 2003, 2004, 2009, 2016 and 2019; Breitling, 2002; Andås, et al. 2007; Bjørlykke, et al., 2010; MenarguesRajadell, 2014), was started in the second half of the 12nd Century ${ }^{1}$, parallelly to the transept, as the first parts of the new Gothic Cathedral, and was firstly completed in a polygonal five-sided apse around the year 1300 (Fischer, 1965; Ekroll, 2009; Bjørlykke, et al., 2010), in times of archbishop Jørund.

Already as far back as 1328, still in times of archbishop Eiliv Arnesson Korte (1311-32), with the construction process ongoing and after a major fire which destroyed grand part of its inner fittings (Fischer, 1965), the design for the apse was changed. In this new design, the inner polygonal end of the building, initially totally opened to the nave, was separated from it while being reshaped in an octagonal core form through

\footnotetext{
${ }^{1}$ Historically attested in the transept's southern chapel, as a project of the archbishop Eystein Erlendsson in the period 1180/83 (Fischer, 1965).

${ }^{2}$ After the marriage of Håkon VI, since 1355 King of Norway, with Margarethe I of Denmark and the death of their son Olav II in 1387, Margarethe I would rule also Norway. The political union of Denmark, Norway and Sweden, from 1397 until 1523, the so-called Union of Kalmar, brought a subordination
}

the insertion of a western screen wall with diagonally placed bays in the north-west and south-west sections, both in a more modern Gothic style (Helle, 1995; Fischer, 1965).

Further major fires $(1432,1451,1531,1718,1719)$, destruction caused by the diverse wars suffered by Trondheim and Norway throughout the history (Findeisen, Petrick, 2002) and especially the loss of significance of Nidaros' archbishopric after 1363 with the partial dependence of Norway to Denmark ${ }^{2}$ and after the forced Reformation of the country on 1537 , left the building to a slow but inevitable ruining process. Only the will of some archbishops like Erik Valkendorff (1510-22) to leave their mark on the building (Ekroll, 2003, 2012; Fischer, 1965; Schøning, 1762), let it be saved from a certain complete destruction, even if with it, as happened with the mentioned fires and wars, many design changes, reparations and renovations were brought to the original building project (Fischer, 1965; Storemyr, Lunde, 1998; Ekroll, 2019). These changes took place especially in the Octagon, lithurgical center of the Nidaros Cathedral with the Shrine of Saint Olav, the most significant religious spot in Norway ${ }^{3}$ since its Christianization, and included notable

of Norway to Denmark - even with the change of name of the city Nidaros to Throndhjem -, only to be surpassed with the independence of Norway in 1814.

${ }^{3}$ After the death of archbishop Gaute Ivarsson (1475-1510), with whom the duke Christian, later Christian II of Denmark, had numerous conflicts, the duke decided to contact the Roman Curia so that a more favorable archbishop could be chosen. Erik Valkendorff would be chosen. The shortly good 


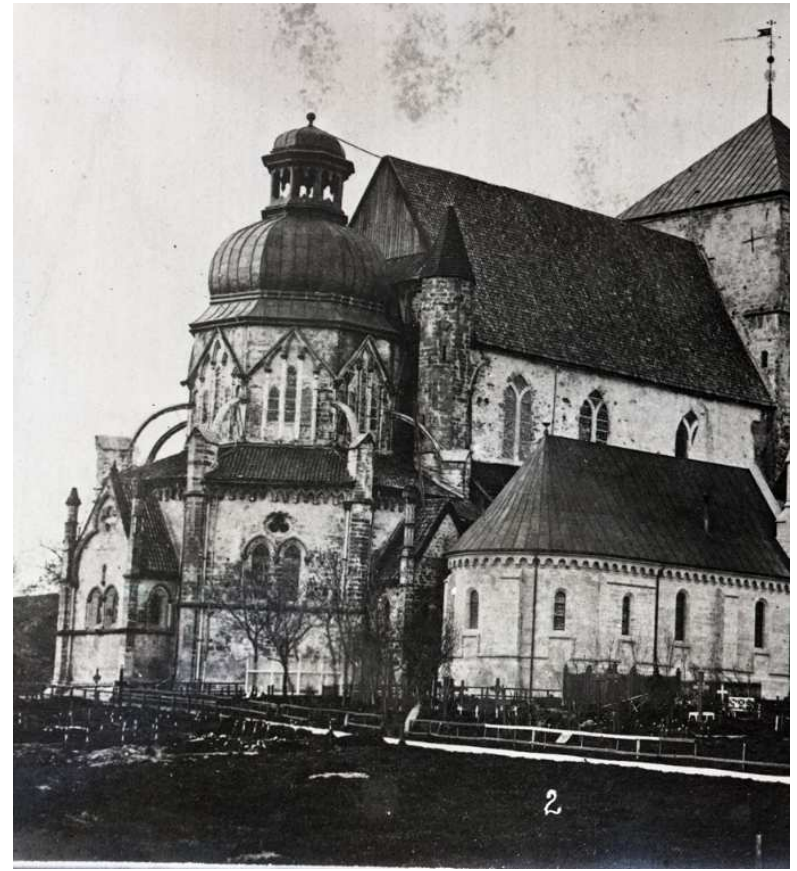

Figure 1. The Octagon before 1872; NDR Archive: Nr. 002

changes in its architectural forms, ornaments and fittings, with a dismantling of lots of its bays partial or completely due probably to a high degradation state, even if respecting highly the original design with the reconstruction process. The accurate extent of the dismantling through the mounting marks (Breitling, 2002; Ekroll, 2016), renovation and all other changes within the Octagon, thoroughly researched, stays yet undetermined. Already in 1531 though, few years after the renovation of Valkendorff, the whole city Throndhjem suffered another major fire. After it and the almost contemporary Reformation of Norway - with the consequent loss of significance of Nidaros -, the Cathedral was left to a slow but unstoppable degradation, with no proper reform or renovation measures. Even after later fires in 1718 and 1719 only inner changes (with new baroque fittings) and minor security measures were realized, among which a new onion roof instead of the burnt historical gothic spire over the Octagon was placed on 1722. (Fischer, 1965; Storemyr, Lunde, 1998) (Figure 1).

It was not until the independence of Norway from Denmark on 1814 that the first important architectonical and archaeological investigations and measures on the deplorable state of the building were planned, which, during the $19^{\text {th }}$ Century, would become the national monument of Norway par excellence (Lysaker, 1973; Duin, 1984; Danbolt, 1997). Already in 1869, the Restoration Office and Workshops Nidarosdomen Restaureringsarbeider (NDR) was founded, and early on 1872, the Cathedral condition would be explored so that its first architect, Christian Christie, could begin with a complete restoration, further building and completion of the Cathedral, and, with it, in its octagonal apse with a reconstruction of the historical spire, 1972-77 (Figure 2).

relationship among both brought for the first time since Medieval times a regular flow of income and wealth to the city, enabling among others the renovation of the Octagon.

${ }^{4}$ Especially the ornamentation stylistic analysis (Fischer, 1965; Rütenik, 2004).

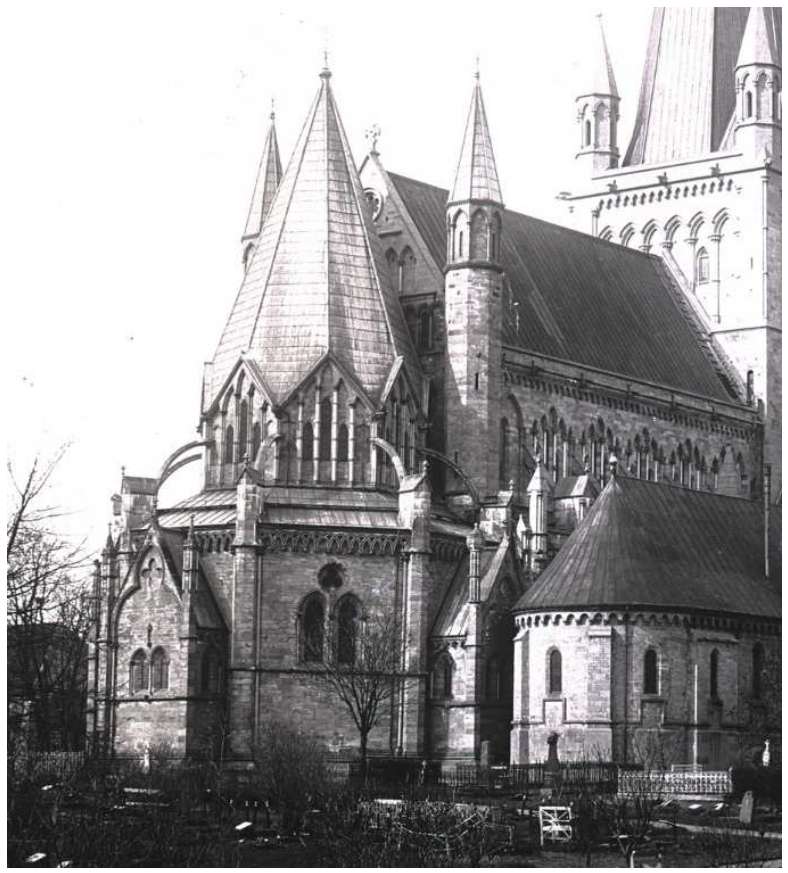

Figure 2. The Octagon after 1888; NDR Archive: Nr. 262

\section{State of art and objectives}

Such intricate history, as it happens with most construction processes in Cathedrals or other complex buildings all over Europe, has been continuously researched since the early $18^{\text {th }}$ and $19^{\text {th }}$ centuries, before and during the major restoration measures (Schøning, 1762; Schirmer, Munch, 1859; Krefting, 1868, 1885; Bergstrøm, 1890, 1892, 1907; Christie, 1907), and until our days, and with it a huge amount of heterogeneous data of disparate accuracy has been produced. This constellation of archival documentation, historical photographies, art historical ${ }^{4}$ and building archaeology analysis, architect journals, material ${ }^{5}$ and pathology mappings, though, stays often disperse, unconnected, unrelated to each other. A complete set of plans and details for the restoration process was not conserved or realized, and only data in the architect journals and some specific plans can be found. Only few efforts have been made in this sense to thematize the restoration process (Fischer, 1965, 1969; Storemyr, Lunde, 1998; Bjørlykke et al., 2010; Ekroll, 2016, 2019). This study is both an attempt to check the feasibility of such a merging methodology, as to measure approximately the workload of this post-process taken from diverse interdisciplinar results into a unique database with equialized accuracy and detail based on graphical plan data of the building.

Even if a complete analysis of the Octagon's changes through time can be here only generally presented, an example in detail of these objectives, methodology and results will be illustrated in the case of the north-western bay of the Octagon (NW, 10196_NV for NDR).

\footnotetext{
${ }^{5}$ Among others, see especially the complete stone material mapping (Storemyr, 1997; 2001, 2002) and Wenk's analysis of the steel roof construction (Bjørlykke et al., 2010).
} 


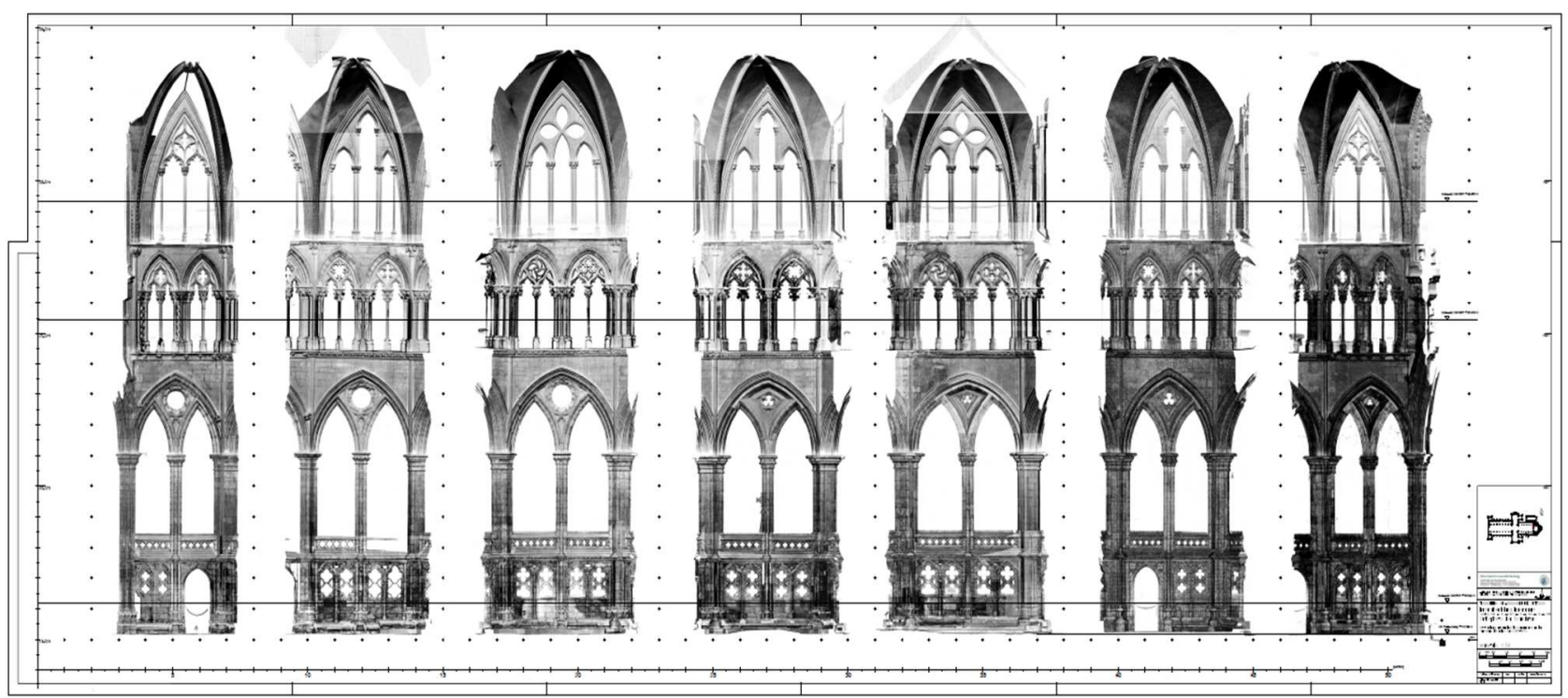

Figure 3. Inner elevation development of the bays NW, N, NO, O, SO, S, SW, except western Screen Wall (clockwise).

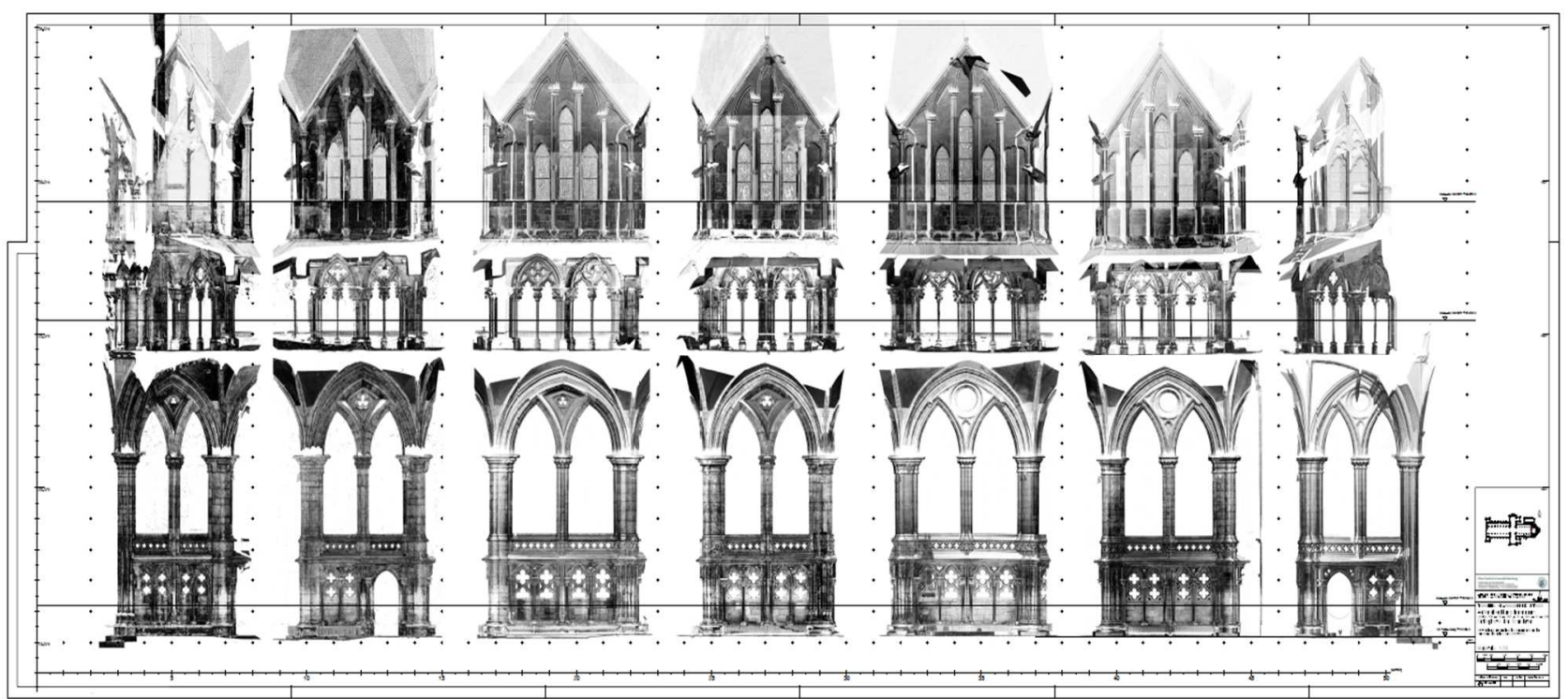

Figure 4. Outer elevation development (from deambulatory) of the same bays SW, S, SO, O, NO, N, NW (anticlockwise).

\section{METHODOLOGY}

In order to generate a complete set of graphical planimetries in scale and with sufficient and stadardized accuracy all over the Octagon in which all these historical informations can be placed, the author has oriented and joined the whole series of still unused 3D-Scan point clouds (GeoScan3D, 2010), ceded by NDR, with Cyclone software, generating floor plans and elevations from the inside and outside in form of orthophotographies (respectively, Figures 3 and 4), double checking existing minor geometrical and scalar deformations in the $\mathrm{z}$-axis due to missing scan positions in the upper floors $(\sim 1,5 \mathrm{~cm})$ and reference points and $\mathrm{x}-\mathrm{y}$-axes deformations

${ }^{6}$ Both the 3D-Scan data and the tacheometrical and manual measurements of the Octagon were ceded for this study, and master thesis of the author (Menargues Rajadell, 2015), by respectively NDR (by its director Steinar Bjerkestrand and archaeologist Øystein Ekroll) and Prof. Breitling, to whom the author wants to express his highest gratitude and recognition between the manual and tacheometrical measurements and the mentioned scans - whose origin is yet to be clarified -, which let assure a plan accuracy on scale 1:20, whilst the historical plans of Fischer can be adscribed to a scale 1:50 and Schirmer's to a level of detail for a scale 1:100. This 3D merged point cloud has been combined both with the manual measurements in the lower screen walls of all bays and the triforium level, and with the tacheometrical measurements realized in the period 1999-2004 by diverse archaeological campaigns tutored by Prof. Breitling. ${ }^{6}$ The 3D Model and measurements were made and drawn during these years by the participants on these campaigns ${ }^{7}$ and $h$ lastly merged and completed in 2014 by the author with the tacheometrical

for all the realized research and knowledge about the construction and restoration in the Nidaros Cathedral.

7 The students and tutors of the archaeological campaings (directed by Prof. S. Breitling) who worked on the manual and tacheometrical measurements and plans from 1999 to 2004 used as a basis to develop the set of elevation and floor plans of the Octagon were, alphabetically, Amman, S.; Assmann, U.; 
measurement of the, until then, still absent area of the steel spire construction over the Octagon and the only partly measured vaulting from above (Figure 5).

Parallely to the generation and post-processing of the elevation orthophotos and plans and their comparison to the historical measurements (Figure 6), with the exportation of the point cloud in other formats to work with ${ }^{8}$, the archaeological campaigns were realized on site between summer 2014 and winter 2015. ${ }^{9}$ The detailed extensive mappings of all the surfaces of the Octagon were done on the previously partly finished tacheometrical elevations with sketched additions manually measured on site.

Before the mapping analysis of all the floor, roof, vault and wall surfaces of the central octagon could began, though, the creation of a complete legend set was fixed, with the expected parameters - found and confirmed in the analysed literature and documentation -, classified in different criteria and groups. Diverse materials were already specified: Soapstone, green slate (theoretically, used from 1050 until 1537), sandstone and marble as the main stone types (Storemyr, 1997); different types of lime and cement mortars (Konow, 2000; Menargues Rajadell, 2015); Construcive special features as fixing or mounting directions, day or period joints, patches or punctual reparations, hints of previously dismantled components, verticality or obliquity of certain components or elements and hoist marks; Damages on the present building materials, in form of cracks in diverse directions, fire damage hints and all other stone or mortar surface or deep damage variations and salt efflorescences; Processing trasses or carving tool marks adscribable at different periods; Special Carving, Mounting or Dismantling marks like stone mason marks, mounting and dismantling marks of $14^{\text {th }}$ and $16^{\text {th }}$ Centuries, respectively; and Other Particularities, like rests of coloration or other unclassified details or information.

Once the mapping of all these criteria, in differential hatch patterns or colours, has been made on all surfaces of the 8 bays of the apse, from the lower screen walls, main arches, triforium and clerestory until its vault and spire, the related literary contemporary descriptions of the building, architect journals, historical photographies or further archival sources have been thoroughly analized, so that the archaeological evidence could confirm the documentation or be confirmed by it therefore adscribing precisely specific components or elements to a period or another. Unclear areas or components have been kept in the representation without a clear depiction.

An analysis of the aforementioned literature and archival documentation for the phase 1510-23, especially of primary sources short before or after the renovation, could show barely a vaguely described state of the whole building and its main geometry, and the exact changes in the Octagon had been mainly related to stylistical analysis. Building archaeological

Bock, K.; Breitling, S.; Busse, O.; Byørlykke, K.; Ebeiler, K.; Elko, A. G.; Fior, M.; Follmar, K.; Hauck, N.; Höpfner, K.; Horrmann, H.; Kannenberg, Ch.; Lange, C.; Malsch, S.; Müller, E. B.; Noell, M.; Petro, S.; Pieritz, A.; Röther, L.; Rütenik, T.; Semmler, A.; Stiehl, S.; Tabbert, B; Tschech, B.; Windelberg, $\mathrm{C}$.

${ }^{8}$ The export of all series of elevations was directly realized in the formats .dxf, .pts, .ptz, .ptg, .e57 as ASCII's .xys and .txt. Visualization problems with the totality of needed measured

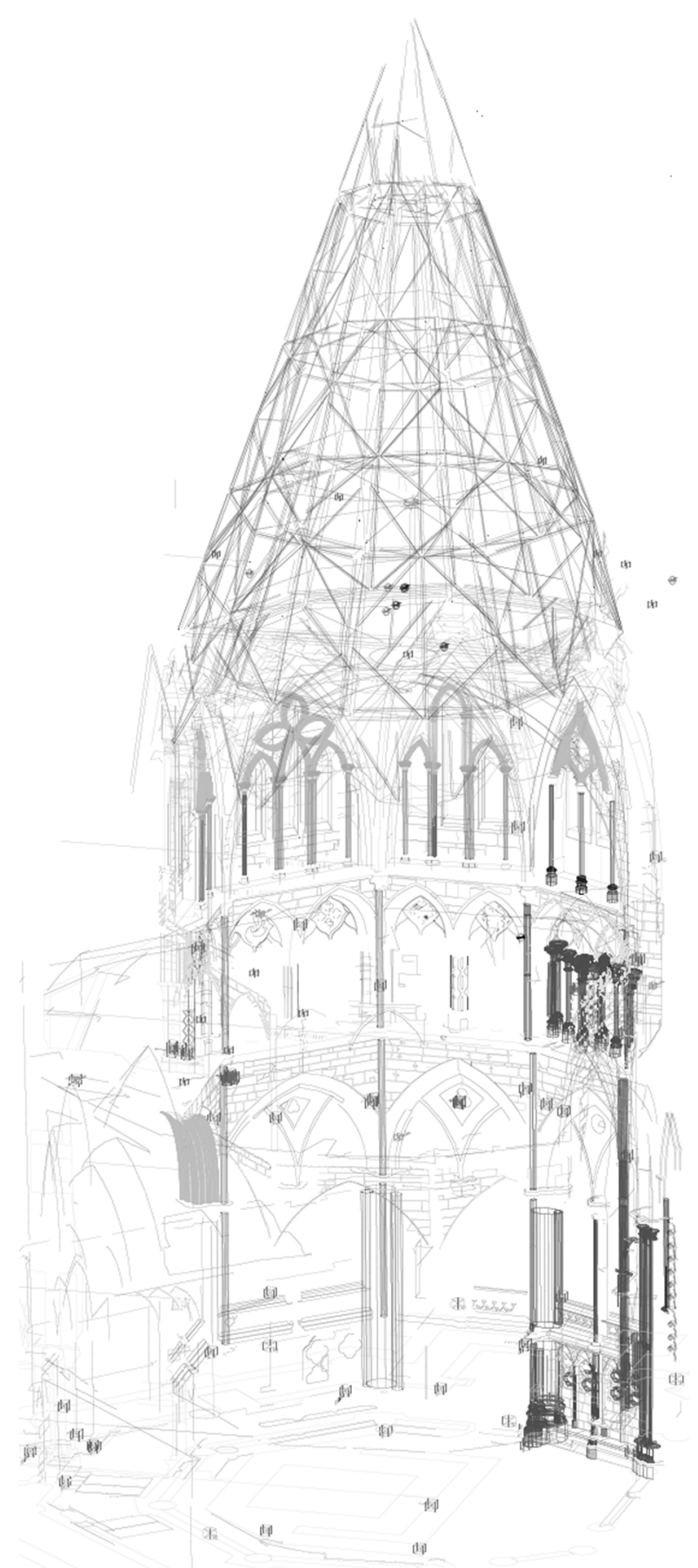

Figure 5. Tacheometrical measurement of the spire over the Octagon (Menargues Rajadell, 2014) merged with the 3Dtacheometrical Model (Breitling et al., 1999 - 2004).

points made the author decide the usage of orthophotos directly from the point cloud, in .tiff-format with horizontally $12-16 \mathrm{kpx}$

${ }^{9}$ Due to the tight schedule of the master thesis and availability and feasibility of research stays on site in Trondheim, some drawing work had to be duplicated, previously sketched on the incomplete tacheometrical plans of former campaigns before the orthophotos could be used as planimetric basis for the investigation on site. 
analysis allows to delve more accurately into the extent of the measures. This has been focused mainly in approximating the extent of the real dismantling process of some bays of this apse through the finding of a series of mirrored-geometrical marks in adjacent stones, which were carved additionally in this period in already placed stones in the Octagon in order to dismantle it orderly, so that the massive mounting process could be simplified. New stones of this period have none of these marks and were carved with different tools as the ones used for medieval stones.

The same research procedure was made in case of Christian Christie's restoration measures in the period 1872-1906 and the later architects Nordhagen and Thiis, yet many more historical photographs before and after the restoration could display in detail which components, materials or areas had been restored, repaired, substituted or changed.

Furthermore, the chemical analysis of 9 mortar samples of the screen wall lower level, triforium and clerestory of the Octagon attempted to confirm again these hypotheses.

All the information from both periods and these different fields has been linked and placed together in the 2 and 3-dimensional representations, and, with it, a more exhaustive, unique and deeper understanding of the complete history of the restoration of the Nidaros Cathedral and all its phases could be achieved. ${ }^{10}$

\section{RESULTS}

\subsection{General results in the Octagon}

The analysis of these criteria have helped detecting from which construction or renovation phase each element or component of the building belonged, in which period it was prepared or mounted in the apse, but also whether if older materials or elements were reused or repaired in later phases. Apart from these general datation criteria, some further topics around the whole process of the Cathedral's restoration and its planning have been found as a result of this methodology:

Since the beginning of the research, the planning phase of the restoration measures has been thematized. The analysis of the historical planimetries, having been superposed, geometrically matched, to the tacheometrical measurements or orthophotos of the referenced 3D-Scan-based point clouds, have shown, on the one hand, that the accuracy of Schirmer's plans of 1859 (Schirmer, Munch, 1859), in a scale of 1:100, was reasonable, yet with measurement accumulated errors of ca. $8 \mathrm{~cm}$. These were the basis for Christie's restoration, who certainly measured the building himself in order to prepare the restoration. A hint for this hypothesis can be seen in the measurements and detail representation plans of Christie's spire design, which are, on the other hand, much more accurate in comparison with the current building (Figure 6). Only minor changes or joint deformations among the metal profiles can be seen as an adaptation on site of the architect's plans.

\footnotetext{
${ }^{10}$ It was through the methods of Building Archaeology, having taken the building as the main source of all investigations, through which the archaeological campaigns directed and assessed by Prof. Stefan Breitling (Breitling, 2002 et al.), tutor of the author in this research, were realized. Their results were later assessed and further used as the base of this investigation.
}

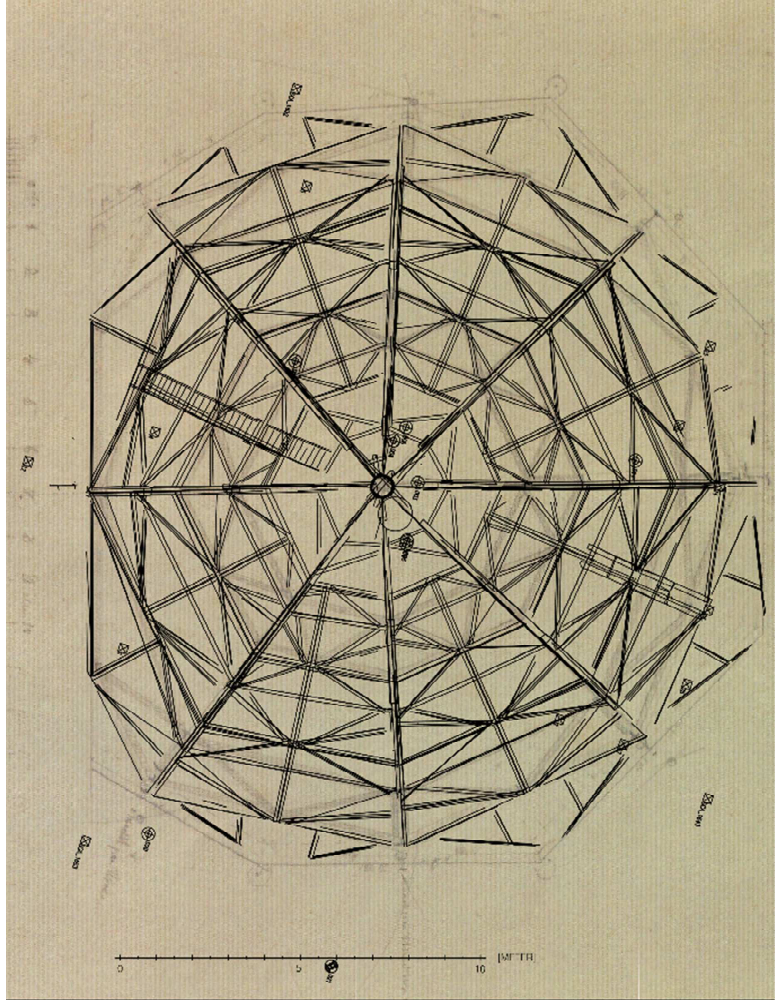

Figure 6. Superposition of the tacheometrical measurement of the author (Menargues Rajadell, 2014) to one of Christie's design floor plan (NDR Archive: Nr. 547)

The accuracy of Christie also is reflected in the details with which he attempted to approach the restoration process towards the original building, as far as possible, through a severe archaeological analysis (Bjørlykke et al., 2010), who learnt after a trip to England from the Cathedral archaeologist Otto Krefting, who had restored with the former Cathedral architect Knudt Guttormsen in 1871-72 the Choir Screen Wall in the western front of the Octagon.

The same case can be noticed by the plans of the later researcher of the Cathedral Gerhard Fischer (Fischer, 1965), as basis for a complete research of the Nidaros Cathedral, which show even a more accurate measurement, from which the 3D-Scan-measured building only differs by merely $2 \mathrm{~cm}$.

This so called archaeological restoration of Christie after the troubles with Schirmer's inventive approach could be especially seen in the comparison of the condition of the building and specifically in the architectural forms and ornaments before and after the restoration measure. A complete relation and reference between both periods has been realized, so that all differences could be marked in the main elevation developments, but also in each one of the historical photographs, so that every changed detail could be noticed and referenced (Figures 7 and 8).

The author has tried as well, as far as posible, to include and adapt those and all results of other ongoing projects, restoration campaings and further research of NDR, with their numeration, reference systems and denominations, so that a complete translatability or interactuability among data could be reached. 


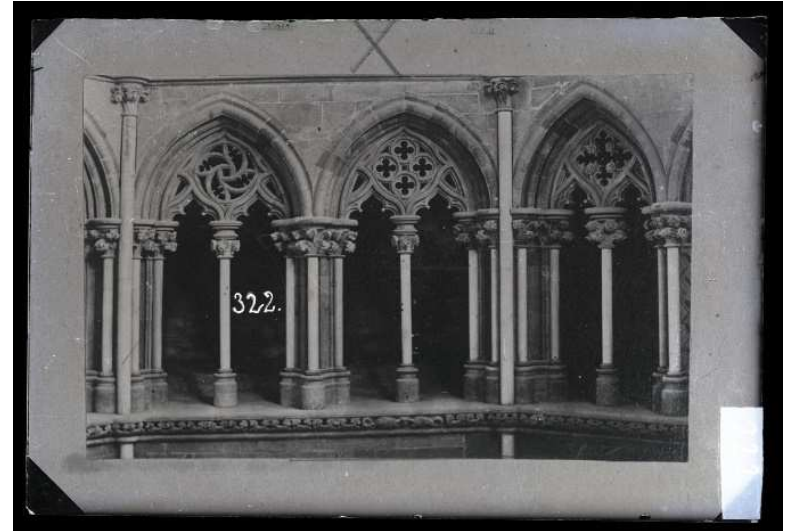

Figure 7. Condition of the North-East bay and half of the East bay after the restoration (NDR Archive: Nr. 322)

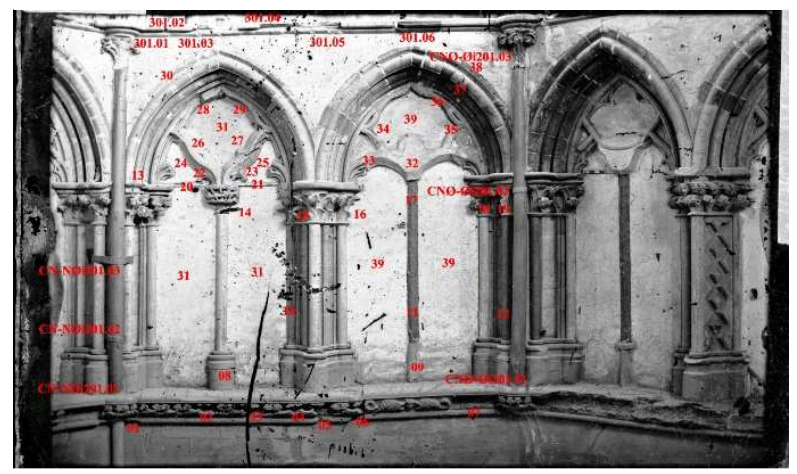

Figure 8. Condition of the North-East bay and half of the East bay before the restoration (NDR Archive: Nr. 186), with the referenced changes and restorations occurred.

The complete archaeological analysis of the Octagon's seven bays and all these findings (exemplified in case of the NorthWestern bay in 3.2) has brought to the possibility to mark all the changed elements within both of these main restoration phases, in the $16^{\text {th }}$ and $19^{\text {th }}$ Centuries (Figures 9 and 10), comparing the situation with the mere orthophotos (Figures 3 and 4).

In order to assure no contradictory datation or depiction of elements or components and consequently to visualize easier the diverse phases occurred in the Octagon, a whole set of elevation plans has been carried out in these levels of detail.

\subsection{Specific results for the North-Western bay}

Illustrating a deeper level of detail of this research, the NorthWestern (NW) bay of the Octagon has been redrawn in CADformat, whilst mapping digitally all the findings found on site through the mapping extension MonuMap (Kubit), connecting manually all further archival sources linked to it. The orthophotography (Figure 10), material mapping (Figure 11), sketched archaeological mapping on site (Figure 12), among many other mapping parameters, have brought to the result of the datation of all constructive elements (Figure 13). This, summarized in the main elevation developments (Figure 9, see next page) show the restorations of Valkendorff's period (in red) and of Christie's restoration (in yellow). Elements unbuilt (light colour), newly built (dark colour) or changed, restored or rebuilt (in stripes).
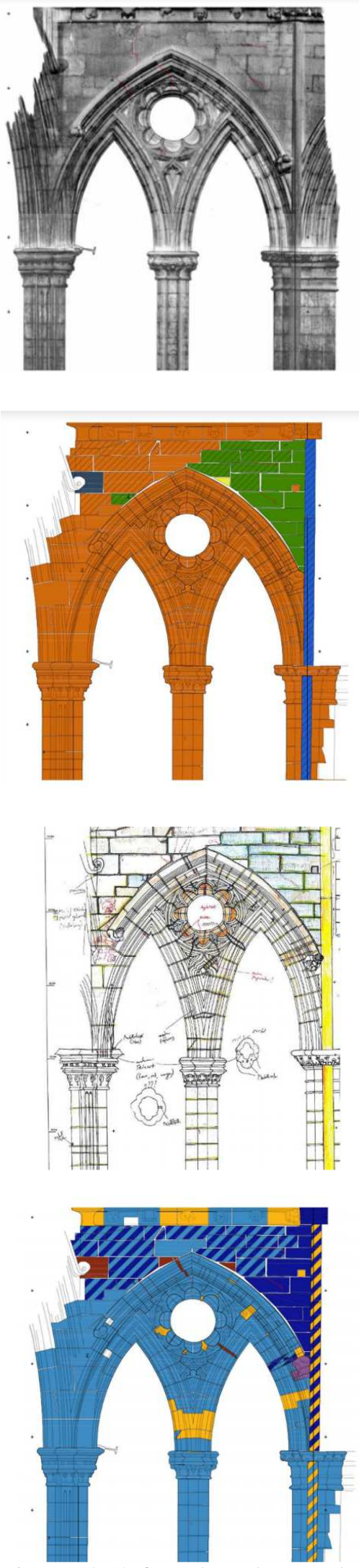

Figures 10-13, from above downwards: Figure 10. Orthophotography Figure 11. Material mapping

Figure 12. Sketch on site of archaeological findings Figure 13. Construction phases (dark blue - before 1300; light blue - 1328 phase; red $-1510 / 23$ phase; yellow $1872 / 77$ phase) 

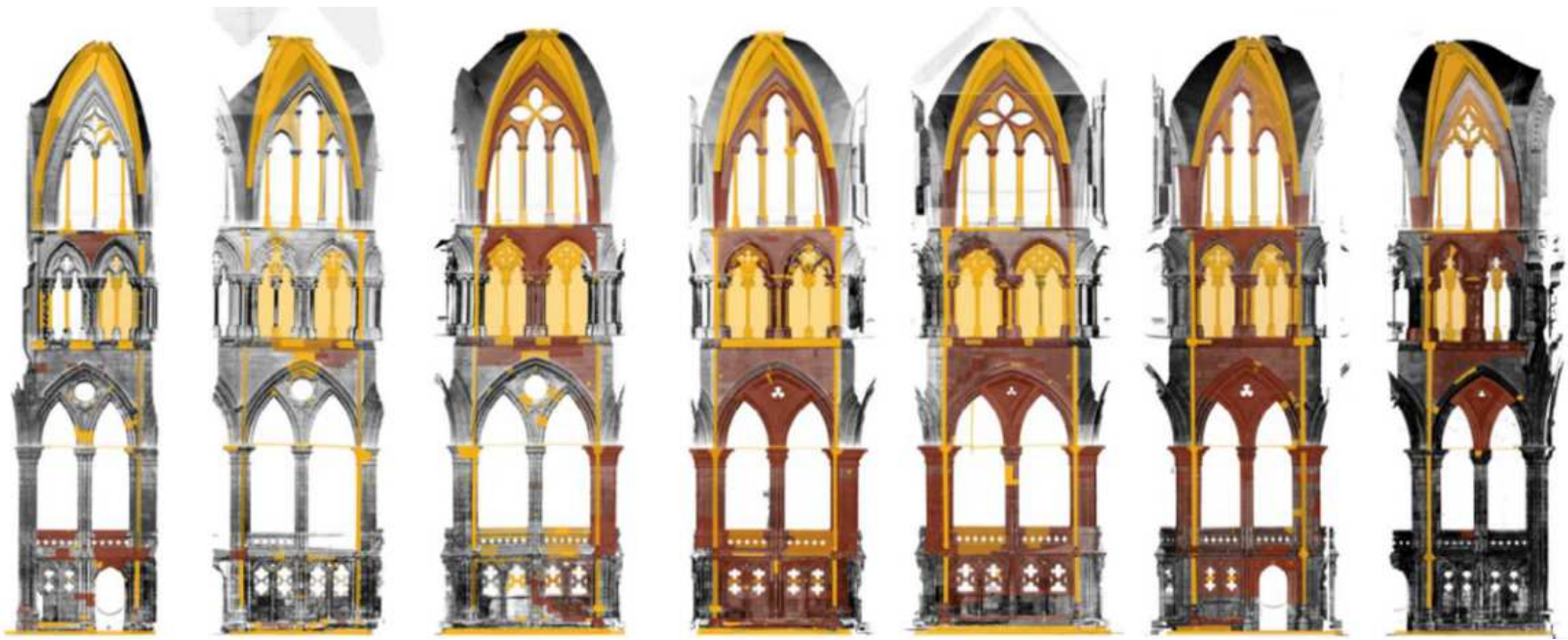

Figure 9. Inner elevation development of the bays NW, N, NO, O, SO, S, SW, except western Screen Wall (clockwise), with all the restoration measures detected through this research (in red-colours the ones from Valkendorff's period and in yellow the ones of Christie's).

\section{CONCLUSIONS, FUTURE DEVELOPMENTS}

It is clear, that in the frame of a master thesis, such ambitious and interdisciplinary project with the attempt of merging such heterogeneous data over more than 4 Centuries cannot be ended, not even by a reduced area as the Octagon within the Nidaros Cathedral. The work in the inner core of the Octagon should be extrapolated to the outer Octagon, and with it, their relationships and connections should be further analysed. The present reseach, though, offers a first attempt to delve into such a methodology and to insist in a complete analysis of interdisciplinary character. A team to work further, within or in close contact to the Restoration Office of NDR could reach rapidly and more effectively bigger areas of the Cathedral, as the parallel work on the diverse working packages of the research slowed down the whole research and limited the level of detail of the other bays of the Octagon.

Further research in other buildings could be approached as well with the same or with an adapted but similar methodology: A complete set of plan and mapping legends, an analysis of all restoration processes and their changes, before, during and after the chosen period, and, structurally, the will to reach a complete compendium of diverse and heterogeneous data should be if not obligatory, highly recommended. With them, the allowance of locating all the mentioned findings, documentary sources, pictures, changes or further notes direct in a unique set of planimetries or 3D-point clouds stays as a logical and direct consequence, and, in each case, can be adapted to the level of detail of the respective research. A graphic plan set for future investigations, though, even if previously measured in variable accuracies or not measured at all, should be counted as requirement for both the mapping and archaeological campaign analysis on site as the literature and documentation source analysis.

Lastly, in order to establish some general considerations about the timeline of the research and the extra workload supposed by the interdisciplinary approach sinchronically in comparison with a usual investigation, the author attempts here to measure particularly each action realized in the frame of the research of the Octagon of the Nidaros Cathedral. A more effective optimization of the work could have surely been found, yet the difficult accessibility of some of the data changed and forced to readapt the procedure to reduce avoidable costs.

\begin{tabular}{|c|c|c|}
\hline Action & $\begin{array}{c}\text { Schedule } \\
\text { WP }\end{array}$ & $\begin{array}{c}\text { Planned / invested } \\
\text { time }\end{array}$ \\
\hline \multicolumn{3}{|l|}{ Office Preparatory Work } \\
\hline $\begin{array}{l}\text { 3D-Scan orientation and } \\
\text { post-processing }\end{array}$ & A & $\begin{array}{l}3 \text { days }+6 \text { days } \\
\text { computing }\end{array}$ \\
\hline Checked accuracy & A. 1 & 1 day \\
\hline $\begin{array}{l}\text { 2D-Elevations and floor } \\
\text { projections in form of } \\
\text { Orthophotos }\end{array}$ & A.2 & $\begin{array}{l}2 \text { days }+20 \text { days } \\
\text { computing }\end{array}$ \\
\hline $\begin{array}{l}\text { 2D-Plans and Layout for } \\
\text { Summer Archaeological } \\
\text { Campaign } 2014\end{array}$ & B.1 & 6 days \\
\hline Literature analysis & C.1 & 64 days \\
\hline \multicolumn{3}{|c|}{ On Site (10 weeks $6 / 8.2014+2$ weeks $12 / 2015)$} \\
\hline $\begin{array}{l}\text { Sketching / measuring } \\
\text { still incomplete plans } \\
\text { (tacheometrical } \\
\text { measured in 1999-2004) }\end{array}$ & $\mathrm{D}$ & 64 days \\
\hline $\begin{array}{l}\text { Mapping of the Octagon } \\
(5 \text { sections in height, } 7 \\
\text { bays, } 2 \text { façaces (in and } \\
\text { out) }=70 \text { sections }\end{array}$ & $\mathrm{E}$ & \\
\hline / section (level, surface) & - & $\sim 1$ day \\
\hline Archival research & C. 2 & 4 days \\
\hline $\begin{array}{l}\text { 3D-Tacheometrical } \\
\text { measurement of the spire }\end{array}$ & B.2 & 10 days \\
\hline Extract Mortar samples & F.1 & 1 day \\
\hline \multicolumn{3}{|l|}{ In Laboratory } \\
\hline Analyse Mortar samples & F.2 & 10 days \\
\hline \multicolumn{3}{|l|}{ Office Post-processing } \\
\hline $\begin{array}{l}\text { 2D- North-Western Bay } \\
\text { CAD-Drawing }\end{array}$ & B.3 & 5 days \\
\hline Literature analysis & C.3 & 20 days \\
\hline Mapping the NW-bay & G.1 & 2 days \\
\hline Mapping $16^{\text {th }}$ restoration & G.2 & 3 days \\
\hline Mapping $19^{\text {th }}$ restoration & G.3 & 4 days \\
\hline $\begin{array}{l}\text { Compilation, Writing, } \\
\text { Archaeological Analysis }\end{array}$ & $\mathrm{H}$ & 50 days \\
\hline Research time (calculus) & - & 275 days \\
\hline $\begin{array}{l}\text { Research time (praxis, } \\
\text { simultaneous actions) }\end{array}$ & - & 180 days \\
\hline
\end{tabular}

Table 1. Timeline of the research with work packages 


\section{REFERENCES}

Andås, M. S.; Ekroll, Ø.; Haug, A.; Petersen, N. H. (Coords.), 2007: The Medieval Cathedral of Trondheim. Architectural and ritual constructions in their European context. Turnhout: Brepols.

Bergstrøm, W., 1890: En del smaa Optegnelser efter K. Guttormsens Regnskapsböger og andre samlede Oplysninger, intil 1876 af W. Bergström (Bergstrøm 1865 - 1890). Trondheim: NDR forlag.

Bergstrøm, W., 1892: En del smaa Optegnelser efter K. Guttormsens Regnskapsböger og andre samlede Oplysninger, intil 1876 af W. Bergström (Bergstrøm I 1865 - 1890). Trondheim: NDR forlag.

Bergstrøm, W., 1907: En del smaa Optegnelser efter K. Guttormsens Regnskapsböger og andre samlede Oplysninger, intil 1876 af W. Bergström (Bergstrøm II 1892 - 1907). Trondheim: NDR forlag.

Bjørlykke, K.; Ekroll, Ø.; Gran, B. S. (Coords.), 2010: Nidarosdomen - ny forskning på gammel kirke. Trondheim: NDR forlag.

Breitling, S., 2002: Fugenbilder. Bauforschung am Nidaros Dom in Trondheim, in: Koldewey-Gesellschaft (Hg.) Bericht über die 41. Tagung für Ausgrabungswissenschaft und Bauforschung vom 31.5.-4.6.2000 in Berlin. Karlsruhe: Koldewey-Gesellschaft-Verlag, S. 89 - 94.

Christie, E. Ch. B., 1907: Throndhjems Domkirke. Innberetninger om restaureringen 1872 - 1907. Trondheim: NDR forlag (repr. 2004).

Danbolt, G., 1997: Nidarosdomen, fra Kristkirke til nasjonalmonument. Oslo: Andersen \& Butenschøn A/S.

Duin, J. J., 1984: Streiftog i norsk kirke historie 1450 - 1880. Oslo: St. Olav.

Ekroll, Ø., 2000:Kirker $i$ Norge. Bind 1: Middelalder $i$ stein. Oslo: Arfo.

Ekroll, Ø., 2003: „St. Olavs skrin i Nidaros”, in Ecclesia Nidrosiensis 1153-1537: Søkelys på Nidaroskirkens og Nidarosprovinsens historie. Trondheim: NTNU forlag.

Ekroll, Ø., 2004: Nidaros Cathedral: The Development of the Building, in Attinger, G., Haug, A. (Coords.): The Nidaros Office of the Holy Blood: Liturgical Music in Medieval Norway. Trondheim: Tapir.

Ekroll, Ø., 2009: Nidaros Domkirke. Trondheim: Nidaros Domkirkes Restaureringsarbeiders forlag.

Ekroll, Ø., 2012: Erkebiskop Erik Walkendorfs (1510-22) byggjearbeid på Nidarosdomens oktogon: provinsiell retardering eller gotisk renessanse?, in Årbok 2012. Oslo: Det Norske Videnskaps-Akademi, S. $251-72$.

Ekroll, Ø., 2016: The Octagonal Shrine Chapel of St Olav at Nidaros Cathedral. An Investigation of its Fabric, Architecture and International Context. Trondheim: NTNU forlag.
Ekroll, Ø. (Coord.), 2019: Katedralbyggerne. Nidarosdomens gjenreisning 1869 - 2019. Trondheim: Museums Vorlaget.

Findeisen, J., Petrick, F. (Coords.), 2002: Norwegen: Von den Anfängen bis zur Gegenwart. Regensburg: Pustet.

Fischer, G., 1965: Domkirken i Trondheim: Kirkebygget $i$ middelalderen. 2 Bde. Oslo: Land og kirke.

Fischer, G., 1969: Nidaros domkirke: Gjenreisning i 100 år 1869-1969. Oslo: Land og kirke

Helle, K., 1995: Under kirke og kongemakt 1130-1350, v. 3 in ANH. nbl.snl.no/Eiliv_Arnesson_Korte (29 June 2019).

Konow, Th. v., 2000: Investigation of Old Mortars at Nidaros Cathedral and Development of Restoration Mortars. Tureida: Report Raphael II Nidaros Cathedral Restoration.

Krefting, O., 1868: Indberetning om en antikvarisk Unders $\phi g e l s e$ i Throndhjems Domkirke 1865 - 66. Trondheim: J.C. Gundersens bogtrykkeri.

Krefting, O., 1885: Om Throndhjems Domkirke. Trondheim: A. E. Kolstad.

Lysaker, T., 1973: Domkirken i Trondheims. Fra Katedral til Sognekirke 1537 - 1869. Bd. 3. Trondheim: NTNU forlag.

Menargues Rajadell, À., 2014: Das Oktogon des Nidarosdoms in Trondheim: Bauhistorische und Bautechnische Untersuchungen über den gotischen Chorbau (1161-1328). Bamberg: (Seminary thesis, NDR archive)

Menargues Rajadell, À., 2015: Das Oktogon des Nidarosdoms in Trondheim: Bauhistorische und Bautechnische Untersuchungen der Sanierungsmaßnahmen bis zum 19. Jh. Bamberg: (Master thesis, NDR archive)

Rütenik, T., 2004: Trondheim (Norwegen), Nidarosdom, Oktogon: Untersuchung der Einzelformen. (Diploma thesis in the TU-Berlin, NDR archive).

Schirmer, Heinrich Ernst; Munch, Peter Andreas

1859 Throndhjems Domkirke / The Cathedral of Trondheim. Kristiania: Fabritius.

Schøning, G., 1762: Beskrivelse Over Den tilforn meget pragtige og Vidtberømte Domkirke $i$ Throndhjem, Egentligen kaldet Christ-Kirken. Trondheim: repr. Tapir, 2004.

Storemyr, P., 1997: The Stones of Nidaros: an applied weathering study of Europe's Northernmost Medieval Cathedral. Trondheim: NTNU forlag.

Storemyr, P., Lunde, Ø., 1998: 130 Jahre Dombauhütte zu Nidaros: Restaurierung gestern, heute und morgen. Trondheim: NTNU forlag.

Storemyr, P., 2001: Thematic Mapping of Stonework at the South Facade of the Nidaros Cathedral Choir. Norway: European Heritage Laboratory. Report no. 2/2001.

Storemyr, P., 2002: Monitoring of Conservation. Test Fields and Conservation. Experiments Based on Lime Mortars 2001 /2002. Zürich: Expert-Center für Denkmalpflege 